$1-2022$

\title{
Sorority Women's Perceptions of Survivors' Services and Justice on an Urban Campus
}

\author{
Andrea Giuffre \\ University of Missouri - St. Louis, amg7v9@mail.umsl.edu \\ Elaine Gunnison \\ Seattle University, gunnisone@seattleu.edu
}

Follow this and additional works at: https://digitalcommons.uri.edu/dignity

Part of the Cognition and Perception Commons, Cognitive Psychology Commons, Criminology and Criminal Justice Commons, Educational Psychology Commons, Health Psychology Commons, Higher Education Commons, Inequality and Stratification Commons, Other Education Commons, and the Social Justice Commons

\section{Recommended Citation}

Giuffre, Andrea and Gunnison, Elaine (2022) "Sorority Women's Perceptions of Survivors' Services and Justice on an Urban Campus," Dignity: A Journal of Analysis of Exploitation and Violence: Vol. 7: Iss. 1, Article 3. https://doi.org/10.23860/dignity.2022.07.01.03

This Research and Scholarly Article is brought to you for free and open access by DigitalCommons@URI. It has been accepted for inclusion in Dignity: A Journal of Analysis of Exploitation and Violence by an authorized editor of DigitalCommons@URI. For more information, please contact digitalcommons@etal.uri.edu. 


\title{
Sorority Women's Perceptions of Survivors' Services and Justice on an Urban Campus
}

\author{
Abstract \\ While researchers have attempted to estimate the prevalence of and identify risk factors for sexual \\ assault, less is understood about the relationship among populations at high risk for sexual assault and \\ their perceptions of survivors' services organizations and justice. The purpose of this investigation is to \\ contribute to existing research through exploratory qualitative analyses of 43 undergraduate sorority \\ women's perceptions of survivors' services and justice on a large, urban campus in the Pacific Northwest \\ in the United States. Results of these exploratory analyses revealed that the sorority women had \\ preferences for informal confidants and services whom they could trust concerning matters of sexual \\ violence. The women also discussed that they would prefer confidential and mental health competent \\ services for fear that disclosing sexual violence might draw public attention to them. On the same note, \\ the women expressed a preference for justice that would prioritize their reputation and minimize \\ stigmatization and highlighted how disclosure of sexual violence could impact their social, educational, \\ and employment opportunities. Moreover, they described a fear of being blamed or not believed about \\ sexual violence. Lastly, participants supported relatively punitive sanctions for perpetrators. Overall, \\ participants cited many barriers to accessing formal support services, exposing the persistent justice gap \\ that remains for this population. Findings suggest a need for outreach regarding campus services \\ designed to address sexual violence.
}

\section{Keywords}

sexual assault, survivors' services, campus victimization, sorority women, secondary victimization

\section{Creative Commons License}

\section{c) $($ i) $\Theta$}

This work is licensed under a Creative Commons Attribution-Noncommercial-No Derivative Works 4.0 License.

\section{Acknowledgements}

The authors would like to thank the anonymous reviewers for their careful feedback and Editor-in-Chief, Donna Hughes, for all of her time, attention, and hard work in assisting us. Dignity thanks the following reviewers for their time, expertise, and recommendations: Kathryn Quina, Associate Dean, emerita, University of Rhode Island, USA; John D. Foubert, Dean, Union University, USA; and Jody Raphael, Senior Researcher (emerita), DePaul University College of Law, USA. 


\title{
DIGNITY AJOURAL OF ANALISIS
}

Volume 7, Issue 1, Article 3, 2022

https://doi.org/10.23860/dignity.2022.07.01.03

\section{SORORITY WOMEN'S PERCEPTIONS OF SURVIVORS' SERVICES AND JUSTICE ON AN URBAN CAMPUS}

\author{
Andrea Giuffre \\ University of Missouri, St. Louis, USA
}

\author{
Elaine Gunnison \\ Seattle University, USA
}

\begin{abstract}
While researchers have attempted to estimate the prevalence of and identify risk factors for sexual assault, less is understood about the relationship among populations at high risk for sexual assault and their perceptions of survivors' services organizations and justice. The purpose of this investigation is to contribute to existing research through exploratory qualitative analyses of 43 undergraduate sorority women's perceptions of survivors' services and justice on a large, urban campus in the Pacific Northwest in the United States. Results of these exploratory analyses revealed that the sorority women had preferences for informal confidants and services whom they could trust concerning matters of sexual violence. The women also discussed that they would prefer confidential and mental health competent services for fear that disclosing sexual violence might draw public attention to them. On the same note, the women expressed a preference for justice that would prioritize their reputation and minimize stigmatization and highlighted how disclosure of sexual violence could impact their social, educational, and employment opportunities. Moreover, they described a fear of being blamed or not believed about sexual violence. Lastly, participants supported relatively punitive sanctions for perpetrators. Overall, participants cited many barriers to accessing formal support services, exposing the persistent justice gap that remains for this population. Findings suggest a need for outreach regarding campus services designed to address sexual violence.
\end{abstract}

\section{KEYWORDS}

sexual assault, survivors' services, campus victimization, sorority women, secondary victimization

$\mathrm{P}$ RIOR EMPIRICAL RESEARCH ON INDIVIDUAL RISK FACTORS for sexual assault have shown that there is a positive, significant relationship among membership in sororities and sexual assault (Barnes et al., 2021; Franklin, 2010; 2016; Kingree \& Thompson, 2020; Mellins et al., 2017; Minow \& Einolf, 2009; Wuthrich, 2009). Additionally, there is an increased sexual assault risk among sorority women who reside in their sorority house (Mohler-Kuo et al., 2004). While it is known that sorority women report greater adherence to traditional gender roles and rape myths (Canan et al., 2016), and they are more likely to misperceive danger cues than their independent counterparts (Norris et al., 1999), and their perceptions about sexual assault services and justice on campuses have been largely overlooked.

The purpose of this research study is to fill the gaps in the literature through exploratory qualitative analyses of undergraduate sorority on a large, urban campus in the Pacific Northwest of the United States. Specifically, the study aimed to learn more 
about the ways in which sorority women perceive sexual assault support services and justice.

Campus studies of sexual violence have typically only attempted to understand the high prevalence of sexual assault among sorority members versus independent students (see for example Barnes et al., 2021; Kingree \& Thompson, 2020; Minow \& Einolf, 2009; Wuthrich, 2009) while a limited number of studies have focused on the impact of secondary victimization on help-seeking behaviors among survivors of sexual assault through qualitative, semi-structured interviews and written surveys (see for example Campbell \& Raja, 2005; Kaukinen \& DeMaris, 2009; Patterson \& Campbell, 2020). Only by directly querying sorority women about how colleges and universities can best respond to sexual assault and what should happen to those who sexually assault sorority women will researchers thoroughly understand survivors' services that may be helpful to this population and how this population conceives of "justice" when sexual assault occurs. Considering sorority women's high risk for sexual assault (e.g., Barnes et al., 2021) and the scant research on sexual assault survivors' perceptions of justice (McGlynn \& Westmarland, 2019), the following research study seeks to understand (1) undergraduate sorority women's perceptions of sexual assault support services and resources; and (2) obtain opinions on what is needed in terms of punishment for perpetrators. The goal of this paper is to address the persistent "justice gap" for sorority women survivors (Lonsway \& Archambault, 2012) and offer research and policy suggestions.

\section{SORORITIES, SECRECY, AND SEXUAL ASSAULT}

Sororities were founded in direct response to the lack of opportunities for female organization and influence on college campuses. As such, sororities developed in an exclusive and secretive manner, hoping to cultivate selective female influence on college campuses (Anson \& Marchesani, 1991). Sorority women often undergo an arduous multi-day recruitment process which promotes fierce loyalty within their organizations (Mongell \& Roth, 1991). Typically, potential new members experience much anxiety over whether they will be offered an invitation to join the sorority of their choice (Atlas \& Morier, 1994). These organizations forbid membership in multiple sororities, and disloyalty to one's member organization is called "lifting" or "dropping." Lifting or dropping is usually followed by expulsion from the organization. Once expelled, sorority women are not allowed access to chapter houses. It is impossible to join another sorority once initiated into one organization (Mongell \& Roth, 1991).

Disloyalty in reference to sororities is difficult to define because sororities are private, autonomous organizations with their own rules and regulations (National Panhellenic Conference, 2021). Moreover, once a woman has joined an organization, their chapter largely controls their lodging, food, and much of their social interactions (Anson \& Marchesani, 1991). Sorority women may not recognize that they are at high risk for sexual violence among people they know (largely because they depend on and trust fraternity men). Female college students are more likely (i.e., 80\%) to be sexually assaulted by someone they know, and the assault is likely to occur at a residence of a friend or acquaintance (Sinozich \& Langton, 2014). Because sorority women are socialized by their chapters and peers to develop strong, positive associations with highrisk situations (i.e., attending fraternity parties) and are pressured to conform to the norms of their chapter and protect the chapter image at all costs, including their own (Cerrito, 2019; Robbins, 2015) sorority women may not be able to distinguish when situations turn dangerous. Due to socialization and general secrecy and isolation of the sorority environment from the rest of campus, sorority women may be at greater 
risk to experience victimization at the hands of fraternity men. Fraternity men are often aware that sorority women face many risks in reporting sexual assault and tend to promote using alcohol as a tool to engage in sexually aggressive behavior (Mustaine \& Tewksbury, 2002).

Fraternity men belong to a culture that works to encourage sexual assault of women through acceptance of myths like "token resistance" whereby when women say no to sexual advances, they really mean yes (Muehlenhard \& Hollabaugh, 1988). Likewise, these all-male groups buffer guilt and shame associated with sexual assault of women and self-promote hypermasculinity to compete with other fraternities in conquest over sorority women. Additionally, alcohol consumption substantially increases women's risk for sexual assault. Researchers have discovered that sorority women drink more alcohol and with greater frequency than independent students (Scott-Sheldon et al., 2008; Wechsler \& Nelson, 2001), impairing their ability to leave risky situations.

\section{PERCEPTIONS OF JUSTICE}

Existing research into perceptions of justice in the context of sexual violence is notably scant, with only a few studies taking open-ended approaches to discovering how survivors conceive of justice in an ideal sense. As such, Lonsway and Archambault (2012) suggest that a justice gap persists for survivors of sexual violence, meaning current methods of adjudication for sexual assault crimes remain disconnected from what is wanted by survivors. Past research in this arena reveals that sexual assault survivors' conceptions of justice do not reflect a conventional model of justice, where justice is almost entirely synonymous with a formal criminal conviction and prison sentence (Goodmark, 2015). Instead, survivors express exceedingly variable perceptions-what McGlynn and Westmarland (2019) term kaleidoscopic justice.

Studies which address this topic remain limited to mostly small, general samples of sexual assault survivors. Although Herman (2005) does not explicitly focus her analysis on survivors of sexual assault, the majority of her 22 interview participants had experienced sexual assault in their lifetime. The participants did not wholly endorse a retributive model or restorative model of justice, but combined elements of the two. The participants wished to see perpetrators disgraced and exposed, but simultaneously wanted to reintegrate with their communities and be, "relieved of their own burden of shame" (Herman, 2005, p. 598). Jülich's (2006) study of 21 adults who had survived childhood sexual abuse reveals similarly broad findings. The 21 participants discussed a reluctance to participate in restorative justice models, reasoning that the models would not protect them from manipulation or power imbalances and that restorative justice was not survivor centered. However, the survivors in Jülich's (2006) study expressed a need to tell their stories in safe forums, have their voices heard, and be more involved in the justice process than currently allowed. McGlynn and Westmarland (2019) interviewed 20 survivors of sexual violence and found that their sample expressed a need for meaningful consequences, recognition of harm, dignity in the justice process, a greater voice, prevention of sexual violence in society, connectedness, and overall justice beyond their individual case.

In the only known study addressing college students views about justice related to sexual violence on campus, Follingstad and colleagues (2021) found that the 846 survey participants in their sample were relatively consistent in applying serious and consequential sanctions to sexual assault cases. Rape myths, however, seemed to influence students' perceptions of adequate sanctions and justice, where scenarios that resembled stereotypical views of rape were assigned harsher sanctions than 
scenarios where the survivor may have engaged in excessive alcohol consumption or initially expressed interest in sexual activity, for example (Follingstad et al., 2021). Considering the limited information on this subject, the current study seeks to build upon this scholarship by ascertaining sorority women's views about justice and the services that are would be most helpful to them in in cases of sexual violence.

\section{THE JUSTICE GAP FOR COLLEGE STUDENT SURVIVORS OF SEXUAL VIOLENCE}

Although the information on survivors' conceptions of justice remains limited, a large body of literature documents the presence of a justice gap (Lonsway \& Archambault, 2012) for college student survivors of sexual violence and informs our work. We divide this literature into two sections. First, we discuss the lack of trust in conventional modes of justice, which is exemplified by limited reporting to police and campus authorities. Next, we relay the limited avenues of recourse and services available to survivors on campus.

\section{REPORTING PAT'TERNS AMONG COLLEGE STUDENT SURVIVORS}

Despite the relatively high rate of sexual violence against college women and especially sorority women (e.g., Barnes et al., 2021), most college students, do not report their assault to the police or campus authorities (Fisher et al., 2003; Sinozich \& Langton, 2014). College women may fear reporting sexual violence to campus police because they believe the incident will be reported to authorities without their express consent due to Title IX regulations, fear the incident could be reported to their parents, fear of reprisal, fear of a trial, belief that their assault was not important enough to report, or that they will not be believed given their age or class standing (Deamicis, 2013; Guerette \& Caron, 2007; Kaufer Busch, 2018; Sinozich \& Langton, 2014). Due to such fears, many women tend to report their assault through unofficial channels. Fisher and colleagues' (2003) analysis of 4,446 female college students from the 1997 National College Women Sexual Victimization Study indicated that around $88 \%$ of college women disclose their experiences of sexual violence to peers. Only $10 \%$ disclosed to family members, $4 \%$ disclosed to a campus authority, $1 \%$ disclosed to a counselor, and less than $5 \%$ officially reported their assault to the police. Fisher and colleagues (2003) make the comparison that the 1999 National Crime Victimization Survey (NCVS) estimated $28.3 \%$ of sexual assaults were reported to the police. This work exposes a much lower official reporting rate when college students are rigorously sampled (Fisher et al., 2003).

Other researchers have also found that college women typically confided in friends, such as a female peer, about sexual violence rather than reporting to formal agencies (Orchowski \& Gidycz, 2012; Orchowski et al., 2009). Additionally, Sinozich and Langton (2014), analyzing NVCS data from 1995-2013, found that $80 \%$ of female sexual assaults on campus go unreported to police, and the most common reasons for not reporting include considering the assault a personal matter or fear of reprisal. Similarly, Dworkin and colleagues (2016) sought to understand whom college sexual assault survivors are likely to contact for help and how survivors characterize their decisions about whom they are likely to contact. In analyses of both survey data and qualitative interviews of 173 survivors, they found that survivors tended to disclose sexual assault to a smaller proportion of their network (made up of friends, family, and significant others) when many network members had relationships with each other or when the network had subgroups, such as cliques. Network connections to the perpetrator added costs to disclosure, where disclosures were more likely to affect 
the perpetrator or people with relationships to the perpetrator (Dworkin et al., 2016).

Certain cultural and institutional barriers also make it difficult for college survivors to report sexual assault. For instance, Spencer and colleagues (2017) analyzed 220 female college students' reasons for not reporting sexual assault. Students who had ever received training on policies related to and prevention of sexual assault were less likely to explain their non-reporting in terms of rape myths or an unfamiliarity with the reporting process (Spencer et al., 2017). Additionally, Holland and Cortina (2017) note that community norms and institutional policies make it challenging for survivors to access sexual assault survivors' services on college campuses (Holland \& Cortina, 2017). For instance, if survivors must make multiple visits to different offices or providers on campus, they are less likely to reach out for support (Stoner \& Cramer, 2019).

\section{AVENUES OF RECOURSE AND SERVICES AVAILABLE TO SURVIVORS}

In addition to issues with official reporting, many college student survivors choose not to seek help via survivors' services. College sexual assault survivors' experiences often interfere with academic performance because perpetrators usually stay on campus due to non-reporting or inaction on the part of the university (Gunnison, et al., 2016), suggesting a need for the current study and a deeper understanding of appropriate services for this group. Survivors may be less likely to seek services or report if they feel ashamed after sexual abuse occurs, or if they blame themselves for the abuse. Also, survivors are also less likely to seek services or report when their assault does not represent a "real rape" or stereotypical portrayal of sexual assault. Further, survivors may be reluctant to seek services or report because of a sense of dependency or reliance on their attackers and/or that their attackers would seek revenge (Fisher et al., 2003).

Out of a national college sample of women with a lifetime history of rape, Amstadter and colleagues (2010) found that posttraumatic stress disorder (PTSD) was the main factor influencing help-seeking behavior. Amstadter and colleagues (2010) discuss that rape survivors were inclined to seek help only when addressing significantly debilitating mental health symptoms. Thus, survivors tend to seek help when they are in dire need (Amstadter et al., 2010). Other researchers, such as Holland and Cortina (2017), have found that logistical issues; feelings, beliefs, and responses that made it seem unacceptable to use campus supports; judgments about appropriateness of support; and alternative methods of coping were major reasons for college women to not seek help after they experienced sexual assault on campus. For those that report their assaults to campus police, withdrawal of participation during investigation is common due to lasting detrimental mental health effects of participating in either on campus investigations or formal criminal justice investigations, termed secondary victimization (Campbell \& Raja, 2005; Orth, 2002; Patterson \& Campbell, 2010). In sum, sorority women are at high risk for sexual assault (Barnes et al., 2021) and an immense justice gap (Lonsway \& Archambault, 2012) exists for college sexual assault survivors. College survivors face many barriers to service access (Holland \& Cortina, 2017), which could be improved upon by asking survivors for their perceptions of service and what constitutes justice. Given the dearth of existing research on sexual assault survivors' perceptions of justice (McGlynn \& Westmarland, 2019) and sorority women's risk for sexual violence (e.g., Barnes et al., 2021), we ask (1) What kinds of support services and resources would sorority women find most helpful in 
the event of sexual assault? and (2) How do sorority women think perpetrators of sexual assault on campus should be punished?

\section{METHOD}

\section{SAMPLE}

In total, 53 sorority women started the survey and 43 completed it. The average age of participants was 20.3 years; $14 \%(n=6)$ indicated they were freshman, $14 \%$ $(n=6)$ indicated they were sophomores, $20.9 \%(n=9)$ indicated they were juniors, and $18.6 \%(n=8)$ indicated they were seniors. Underclasswomen (i.e., freshmen and sophomores) made up $28 \%$ of the sample while upperclasswomen (i.e., juniors and seniors) made up $39.5 \%$ of the sample. Fifty-eight percent $(58.1 \%, n=25)$ of participants indicated that they identify as heterosexual, $4.7 \%(n=2)$ of participants indicated that they identify as bisexual, and $37.2 \%(n=16)$ did not report their sexual orientation. Non-response on this question is speculated to be due to exceptionally heteronormative culture within sororities and fraternities (Grigoriadis, 2017) or reluctance by minority participants to answer (Kim \& Fredriksen-Goldsen, 2013). When asked about their race, $53.5 \%(n=23)$ of participants identified as white, $9.3 \%(n=$ 4) of participants identified as Asian, 2.3\% $(n=1)$ of participants identified as both Hispanic and white, and 34.9\% $(n=15)$ did not report their race. Further, 39.5\% $(n=$ 17) of participants indicated that they did not live in their chapter house, while $30.2 \%$ $(n=13)$ of participants indicated that they did live in their chapter house, and $30.2 \%$ $(n=13)$ of participants did not report their living situation. The complete breakdown of demographics can be seen in Table 1.

\section{DATA COLLECTION AND RECRUITMENT PROCEDURES}

Utilizing qualitative methods, this study was designed to assess urban undergraduate sorority women's perceptions of survivors' services and opinions about justice on a large urban campus with over 46,000 students in the Pacific Northwest United States. At this campus, there are a total of 19 sororities consisting of approximately 2000 members with roughly 1500 members, or $75 \%$, residing in chapter houses. We employed an online survey using Qualtrics in order to maintain as much anonymity among participants as possible. We sought and received IRB approval from the end of March 2018 to the middle of May 2018. Due to IRB requirements, questions that were originally included in the survey that asked about subject's trauma history, whether an assault was reported if one occurred, and access to services had to be dropped from this research investigation. Given this limitation, the survey aimed to address perceptions of the group of sorority women surveyed in a vignette-like style. For example, one section of the survey began with the prompt, "The following questions ask about how you think a fellow sorority sister would respond if she were sexually victimized." Research asking participants to respond to hypothetical situations have done so from many perspectives including both peer and personal viewpoints (Hughes \& Huby, 2004). Prior research has demonstrated the validity of inviting participants to act as consultants in discussing how peers and others may react in certain situations (Foxx et al., 1989; Friedenberg et al., 1993; Kendall et al., 1997) 
Giuffre and Gunnison: Sorority Women's Perceptions of Services and Justice

Table 1. Demographics of Participants $(n=43)$

\begin{tabular}{|c|c|c|c|}
\hline Variable & $f(\%)$ & Variable & $f(\%)$ \\
\hline Age & & Political Affiliation & \\
\hline 18 & $2(4.6 \%)$ & Liberal/Democrat & $20(46.5 \%)$ \\
\hline 19 & $7(16.3 \%)$ & Moderate & $4(9.3 \%)$ \\
\hline 20 & $5(11.6 \%)$ & Independent & $1(2.3 \%)$ \\
\hline 21 & $11(25.6 \%)$ & Not reported & $18(41.9 \%)$ \\
\hline 22 & $4(9.3 \%)$ & & \\
\hline Not reported & $14(32.6 \%)$ & & \\
\hline Year in school & & Religious Preference & \\
\hline Freshman & $6(14 \%)$ & No preference & $22(51.2 \%)$ \\
\hline Sophomore & $6(14 \%)$ & Christian Denomination & $7(16.3 \%)$ \\
\hline Underclasswomen & $12(28 \%)$ & Not reported & $14(32.6 \%)$ \\
\hline Junior & $9(20.9 \%)$ & & \\
\hline Senior & $8(18.6 \%)$ & & \\
\hline Upperclasswomen & $17(39.5 \%)$ & & \\
\hline Not reported & $14(32.6 \%)$ & & \\
\hline Major & & $\begin{array}{l}\text { Sorority Membership } \\
\text { Length }\end{array}$ & \\
\hline Social Sciences & $15(34.9 \%)$ & $<1$ year & $4(9.3 \%)$ \\
\hline Business & $4(9.3 \%)$ & 1 year & $3(7 \%)$ \\
\hline Engineering & $4(9.3 \%)$ & 2 years & $7(16.3 \%)$ \\
\hline Hard Sciences & $3(7 \%)$ & 3 years & $7(16.3 \%)$ \\
\hline Double major & $2(4.7 \%)$ & 4 years & $7(16.3 \%)$ \\
\hline Not reported & $15(34.9 \%)$ & Not reported & $15(34.9 \%)$ \\
\hline Transfer student & & Living Situation & \\
\hline No & $29(67.4 \%)$ & Outside chapter house & $17(39.5 \%)$ \\
\hline Yes & $1(2.3 \%)$ & Within chapter house & $13(20.2 \%)$ \\
\hline Not reported & $13(30.2 \%)$ & Not reported & $13(30.2 \%)$ \\
\hline Race & & Recruitment Method & \\
\hline White & $23(53.5 \%)$ & Formal Fall Recruitment & $24(55.8 \%)$ \\
\hline Asian & $4(9.3 \%)$ & Continuous Open Bidding & $5(11.6 \%)$ \\
\hline $\begin{array}{l}\text { Hispanic and } \\
\text { White }\end{array}$ & $1(2.3 \%)$ & Not reported & $14(32.6 \%)$ \\
\hline Not reported & $15(34.9 \%)$ & & \\
\hline Gender identity & & Sexual orientation & \\
\hline Female & $28(65.1 \%)$ & Heterosexual & $25(58.1 \%)$ \\
\hline \multirow[t]{2}{*}{ Not reported } & $15(34.9 \%)$ & Bisexual & $2(4.6 \%)$ \\
\hline & & Not reported & $16(37.2 \%)$ \\
\hline
\end{tabular}


Previous literature utilizing similar methodology to the current study also demonstrates that focusing on a third party through a hypothetical lens helps to desensitize potentially sensitive research topics (Finch, 1987; Foxx et al., 1989; Hughes \& Huby, 2004). Asking participants to focus on sorority women's perspectives as a whole rather than their own can limit secondary trauma regarding discussions of sexual assault (see Campbell et al., 2019).

In order to gain access to this population, the principal investigator sent sorority chapter executive boards a formal letter via email to gain consent to present information about the survey at weekly chapter meetings. The letter outlined the aim of the survey, discussed the length of the survey, indicated that the survey was online, explained that participation was completely voluntary and confidential, and provided contact information for the principal investigator and IRB. Six chapters responded to the email request and allowed the principal investigator to read aloud the same letter at weekly chapter meetings and answer any questions about the survey. The precise number of sororities contacted is not disclosed as it would likely reveal which university in which the sororities were situated. However, it is approximated that about $1 / 3$ of the total sororities that were contacted ended up participating in the study and the sorority population at the university of study was estimated to include approximately 2,000 members. At these meetings, the principal investigator provided the sorority women a Qualtrics survey link and QR code to access the online survey. After the meetings took place, the principal investigator sent the six chapters' executive boards the Qualtrics survey link and QR code two additional times to garner more response. One month time elapsed between the email reminders. The survey was designed to be completed in 15 minutes and contained a total of 34 questions.

\section{RESEARCH DESIGN}

In the online survey, original questions were designed to explore sorority women's perceptions of the helpfulness and likeliness to access survivors' services on their campus as well as justice. We took a survivor centered approach and deliberately asked about these services given prior research indicating survivor perceptions reach far beyond the courtroom (McGlynn \& Westmarland, 2019). Survey questions also included mandatory items indicating that the participant was over the age of 18 , freely consented to participation, and was an undergraduate sorority woman at the particular university of study. Due to the exploratory nature of the study, the online survey instrument was primarily designed to be open-ended aside from questions regarding demographics. In this analysis, we focused solely on open-ended questions designed to tap participants perceptions of sexual assault survivors' services and justice. Survey questions asked sorority women information like, "When sexual assault occurs, what are the three best ways that college/university campuses can respond?" and "What should happen to people who sexually assault sorority women?"

\section{ANALYSIS}

We utilized an inductive, thematic coding approach to analyze data from our survey (Rubin \& Rubin, 2016). Beginning with "justice gaps" as a starting point, or sensitizing concept, for our analysis (Blumer, 1954), we sought to identify the repeating patterns both within and between survey data to constitute our themes and also search for any evidence that would refute those themes (Glaser \& Strauss, 1967). First, the principal investigator open-coded the data line-by-line, where small sections of survey data were each given basic descriptions to specify what that data means (Glaser, 1978). Then, the principal investigator conducted a second round of 
focused coding to hone in on the repeated themes and subthemes in the data. Last, the principal investigator engaged in intensive discussion with the second author as a check on data interpretation (Saldana, 2016).

\section{FINDINGS}

The survey explored a diverse array of sorority women's perceptions of survivors' services and justice related to sexual assault, but a few key themes emerged within the data. First, the sorority women expressed a clear preference for informal support services. Second, sorority women relayed that they would be more likely to access survivors' services that are confidential in nature and competent to address mental health concerns. Third, the women's reputation and stigmatization dominated their concerns about going through official channels to report sexual assault. Last, the women expressed relatively punitive opinions about appropriate sanctioning in sexual assault cases. The following sections explore each of these themes in detail.

\section{PREFERENCES FOR INFORMAL CONFIDANTS AND SERVICES}

Sorority women were asked about whom they would trust in matters concerning sexual violence and expressed a preference for informal support within the tightly knit social networks of their chapter and the Greek system. In total, 40 women, or $93 \%$ of women, who participated in the survey specified whom sorority women would trust if they or a sorority woman they knew experienced sexual assault. When asked about whom they would trust to provide assistance with public safety issues on campus, the participants most commonly expressed (85\%) that they would trust informal support services such as other sorority women, chapter leadership, and friends. Participants noted that, "Sometimes sorority women trust fraternity men to walk them home at night and usually hang out in groups to make sure they're safe" and that they would sometimes trust, "police, but doesn't usually work out well. I would guess mostly friends helping out other friends." In comparison, only 41\%, or 16 women who answered the question discussed that they would trust formal services like the police, campus health and wellness supports, doctors, or safety escort services provided by their campus. One woman indicated, "Sorority women trust their friends (other sorority members) and maybe police if the issue is serious enough."

Similarly, 40 sorority women, or $98 \%$ of the women who provided answers about who they would tell about sexual assault, indicated that they would tell officers in their sorority, big sisters and little sisters, members of their pledge class. In some instances, sorority women explained that sorority women might reach out to a counselor/therapist or a doctor, but only 15 of the women expressed such a preference. When asked who they would not tell about sexual violence, 42 participants, or $97 \%$ of the women whom answered this question, expressed that they would not be likely to tell fraternity members, members of other sororities, campus police, campus medical, professors, teacher's assistants, and university administrative personnel.

\section{CONFIDENTIAL AND COMPETENT SERVICES}

Participants said that they would be more likely to access survivors' service organizations that are private or confidential in nature and those that are equipped to handle mental health issues. In total, 36 participants discussed why sorority women would be likely to access particular services, and 21 women, or about $58 \%$, noted that sorority women would prefer confidential services. About one third, or 11 of the women, discussed mental health services directly. Secondarily, these women noted that they would be more likely to access survivors' services that would not jeopardize 
their schooling or employment, could handle additional medical concerns, and that are free. The sorority women explained that they would access organizations that they knew, "would trust their opinions, feel respected, and focus on mental health" as well as services they felt they can trust, and "not to spread rumors or talk to others about the situation." The participants indicated that they would not be likely to access organizations they felt would bring public attention to them, bring feelings of shame, lack empathy, push them to make certain choices, and not treat them with respect. One woman described that sorority women would be most likely to access services which were, "private and feel most comfortable with them. Wouldn't be pressured to make decisions." Others were concerned that organizations lacked resources and training to deal with mental health issues adequately when they stated sorority women, "need counseling, medical, or someone to talk to" would, "get help from people who they know are experienced in dealing with it" and "need emotional and mental health support." Moreover, one woman discussed:

Sorority women might be more likely to seek help from organizations that don't officially belong to the university. I know I wouldn't want the university to have that kind of information about me and I wouldn't want to get in trouble for any reason by talking to the police or doctors that work at the university.

Additionally, these same participants noted that some services might be too expensive to access or that the sexual assault might not be serious enough to access services. One participant highlighted that sorority women would be likely to look for services that were, "easy to access, feel more confidential, and some are free." Another described, "The counseling center and Student Health Center only provide one free visit per quarter so it is difficult to go to any of the university medical centers because most of us cannot pay for any visits after that." In the end, much of the explanations that sorority women gave centered around whether or not services could be considered confidential and competently address mental health concerns after sexual violence, but the women were also focused on the legal ramifications of seeking help and the cost of services.

\section{REPUTATION AND STIGMATIZATION}

Participants were then asked to list the most common reasons that a sorority woman might not feel comfortable officially reporting sexual violence, and 35 women expressed their opinions on this subject. Corresponding with the previous theme focused partly on confidentiality, 30 participants, or about $86 \%$ of the women who discussed this topic, relayed concerns about reputation and stigmatization when officially reporting sexual violence. Women cited the lack of support from their chapter, Panhellenic, fraternities, the Intra-Fraternity Council (IFC), police, courts, and parents as reasons for not officially reporting sexual assault. One woman's perceptions summed up this theme, relaying potential consequences of reporting:

If it's officially reported then people risk the information getting spread across the Greek system so that frats might find out. If that happened then our reputation could be ruined so we wouldn't be invited to participate in philanthropies. I think people also are afraid of incriminating themselves by talking to police and medical professionals. Sorority women might also be afraid that they would get sent to judicial if the chapter found out they were drinking or doing drugs when they were assaulted.

Paramount in this woman's answer were the potential social and legal ramifications for speaking out about sexual violence. Along those lines, others mentioned that sorority women might "fear that other chapters would not want to have events with 
a chapter that accused someone of sexual assault," and "I think they might be afraid that if they were to report then they would be seen as responsible if a frat got shut down." Some participants mentioned the reputation of the Greek system more generally, stating that sorority women may not be likely to officially report because they "Wouldn't want to damage the reputation of their friends or people in the Greek system by going public" and "Too much attention and puts a bad light on the Greek system."

The women were aware that others may not believe them about or blame them for sexual assault. The women said that they would not feel comfortable reporting due to, "embarrassment, harassment, scared" and, "she worries she won't be believed, she is ashamed, she is afraid." Others specified that they were concerned about their reputation and that there is "too much stigma about calling people out." Participants said that officially reporting sexual assault might produce harassment and that they feared, "information being spread, don't want to get kicked out of chapter, losing friendships/family." One participant made the statement that official avenues of recourse would possibly narrow school and work opportunities when she said, "might miss school or work to deal with a very public process. Could make people think differently about them." As a subtheme, participants also mentioned that they thought sorority women would hesitate to officially report sexual assault because they do not want to involve their parents or have to pay for legal advice. Another woman noted that sorority women would be unlikely to officially report sexual violence because they “can't pay for services, wouldn't want parents involved, might impact reputation on campus in chapter and as an individual."

\section{PUNITIVE PREFERENCES FOR SANCTIONS}

When participants were asked to explain what should happen to people who sexually assault sorority women, they generally expressed a preference for removing known perpetrators from campus and their fraternity, if applicable. Perhaps their reported preference is due to their strong identification with the Greek system as opposed to the student perpetrator. Approximately $88 \%$ of the women who answered this question, or 38 women, noted that individuals who sexually assault sorority women should be removed from campus and/or their fraternity by way of campus adjudication, criminal trial, and incarceration. Additionally, 35 of the women, or $81 \%$ of the women who answered this question expressed that they wanted perpetrators of sexual assault against sorority women to have cases adjudicated through the criminal justice system. Specifically, participants stated that people on campus who sexually offend should be, "kicked out of their fraternity and the police should intervene," "removed from Greek system if in it," and "kicked out of their frat and college." Others suggested that "they should be taken into custody and put through the trial process" and that "they should serve jail time and go on the sex offender list." One woman noted, "The degree of the assault certainly matters. But any level of sexual assault should result in the removal from the Greek community. The school should then decide on either a suspension or expulsion." Only 5 women, or about $12 \%$, expressed a preference for therapeutic intervention. These women suggested that individuals who sexually assault sorority women "need to go through training so it doesn't happen again and go to prison," "should not be allowed on college campuses and should be taken to court," and should be "prosecuted in court, leave campus, have to undergo treatment." In the end, the responses were relatively consistent across the participants, highlighting a preference for removing offenders from the campus environment even when combined with other therapeutic suggestions. 


\section{DISCUSSION AND CONCLUSION}

The findings in this study portray additional evidence that researchers should attempt to understand the myriad ways in which individuals at high risk for or those who have experienced sexual violence conceive of justice. Although four main themes emerged, the participants conceived of justice in ways comparable to McGlynn and Westmarland's (2019) kaleidoscopic justice. It is important to denote that the themes presented here represent repeated patterns both within and across surveys, but the conceptions of how the participants viewed survivors' services and justice represent a diverse array of interests. Thus, we concur with McGlynn and Westmarland's (2019) finding that studies such as ours barely scratch the surface for what is needed to close the sexual violence justice gap. Our study builds on previous literature by demonstrating that sorority women are another population which conceives of justice in this manner.

The women in this study also indicated heavy reliance on informal support services such as other sorority women, chapter leadership, and friends to provide assistance with public safety issues. Sorority women also discussed that they would tell officers in their sorority, big sisters and little sisters, and members of their pledge class about sexual assault. Because participants reported that they would rely on specific groups of other sorority members rather than the entire sorority and were concerned with confidentiality, Dworkin and colleagues' (2016) work indicating that college survivors of sexual assault only trust a few, key individuals for fear of exposure to perpetrators appears to apply to the specific population of sorority women. The findings from the current study also add to existing literature suggesting that sexual assault survivors typically trust a few, key informal support sources for fear of secondary victimization in the criminal legal system (Ahrens et al., 2007; Dworkin et al., 2016; Starzynski, et al., 2005). Additionally, the findings suggest that if sorority women are reluctant to report and tend to rely on their members for support, perhaps it signals that sororities should develop strategies to prevent the likelihood of sexual assaults in their respective chapters.

The second theme highlighted participants' preference for confidential and competent services in terms of mental health. Their narratives are in line with the existing research that outlines the stigma and fear of backlash associated with reporting sexual assault through official channels (Deamicis, 2013; Guerette \& Caron, 2007; Kaufer Busch, 2018; Sinozich \& Langton, 2014). At the same time, the emphasis on respectful communication with service providers aligns with much of the research concerning sexual assault survivors' perceptions of justice. Our work and this existing information both relay the need for modes of justice that do not carry risk of shame and allow survivors to tell their stories and have their voices heard (Herman, 2005; Jülich, 2006; McGlynn \& Westmarland, 2019). Our findings also appear to comport with Holland and Cortina's (2017) discussion that judgments about the appropriateness of support services may interfere with sexual assault survivors' decisions to seek help. Once again, this finding suggests that sororities need to develop strategies to prevent incidences of sexual assault in the first place so that members are not reliant on mental health support systems to which they may or may not have access.

Also, in line with prior research on sexual assault reporting practices (Fisher et al., 2003; Orchowski \& Gidycz, 2012; Orchowski et al., 2009), participants mentioned many perceived barriers to officially reporting sexual assault. Participants cited the lack of support from her chapter, Panhellenic, fraternities, the Intra-Fraternity Council (IFC), police, courts, and parents as reasons for not officially reporting sexual assault. 
The finding that participants cited the lack of support from her chapter as a barrier to reporting is especially troubling, and it highlights that sororities need to review and revise their cultural norms and practices and work on establishing programming that educates their members on strategies to prevent victimization. Others were concerned about their reputation and the stigma around speaking out about sexual assault. Additionally, participants stated that officially reporting sexual assault might produce harassment, which would secondarily victimize them (Campbell \& Raja, 2005; Orth, 2002; Patterson \& Campbell, 2010). The sorority women surveyed seemed to be aware of the potential for secondary victimization including the risk for disbelief, blame, and refusals of help on the part of university services, others in the Greek community, and their parents.

The women surveyed appeared to fear betrayal from their own community when they discussed that they feared not being invited to social events, being cut off from friends, and being sanctioned by their chapter for consuming alcohol or drugs. Sweet (2004) notes that college students have a need for belonging on campus, but the relative isolation of Greek life from other social spheres on campus and valuation of secrecy and exclusivity of these organizations can foster dangerous conditions which promote hazing and sexual assault. It is important to note that members of Greek organizations may also be reliant on their chapters as institutions for housing and food (Anson \& Marchesani, 1991), so there is potential fear that they may not have access to basic resources if they divulged secrets or spoke negatively about their organization. We argue that this fear and risk for disbelief, blame, and refusals of help exemplify the severity of the "justice gap" present for sorority women survivors of sexual assault. Although sorority women are at very high risk for sexual assault (Barnes et al., 2021; Franklin, 2010; 2016; Kingree \& Thompson, 2020; Mellins et al., 2017; Minow \& Einolf, 2009; Wuthrich, 2009), the findings presented here suggest that the women may not be likely to seek help, if at all, from official channels. Perhaps only in serious cases of mental health issues would the women reach out (Amstadter et al., 2010).

Interestingly, the findings supported the notion that sorority women would rely heavily on formal sanctions against sex offenders on their campuses. Indicating similar preferences to general student populations (Lake, 2009), participants discussed that they wanted their university to take action against offenders, yet they reported many barriers to accessing services. While participants perceived many formal services (e.g., police response and campus adjudication) as unhelpful to sorority women or that sorority women would be unlikely to access formal services, they still expressed a desire for their campuses to take action against known perpetrators. These results suggest that sorority women lack trust in their universities and the police, but have clearly defined opinions about what constitutes "just" punishment in cases of sexual assault. Similar to Follingstad and colleagues' (2021) analysis, the sorority women perceived "justice" in harsh terms, perhaps leading to further distrust of police university adjudication systems when expectations do not align with reality.

\section{LIMITATIONS}

The current study was not devoid of limitations. The primary issue of concern with this study is the sample size. In total, 43 sorority women at a large, urban university in the Pacific Northwest answered the survey. Despite repeated attempts at contacting sorority women to take the survey, only six chapters responded to the researcher's request. The study was exploratory in nature and only attempted to garner enough response to determine the range of possible responses by sorority women 
and any repeating patterns of themes. Apart from the small sample size, another limitation of the sample was the lack of racial and ethnic diversity and the likelihood that the sample were from middle to upper socioeconomic backgrounds. Thus, it is possible that some responses may reflect the demographics of the sample and not the Greek culture per se. Given the strong overlap between these characteristics, it is difficult to disaggregate them. Further, the sample limits generalizing the results to other sororities, including those developed for and by African-Americans. Another issue of concern with the study was that participants were not asked about prior sexual assault. In order to improve the validity of future analyses on this topic, participants should be asked directly about their experiences with sexual assault to determine how sexual assault survivors' services should be tailored to fit sexual assault survivors' needs rather than those at high risk for sexual assault.

\section{DIRECTIONS FOR POLICY AND FUTURE RESEARCH}

While this research was exploratory, one critical policy implication is the need for sexual assault prevention programming in sororities, in which intensive training is implemented in the chapter to assist members in learning about what factors can contribute to sexual assault (e.g., drinking) and to develop solutions to reduce the likelihood of victimization (see Shapiro, 2015). Another possible policy consideration is the need for outreach on behalf of formal campus supports. Because the findings of this study suggested that the sorority women feared formal support services would secondarily victimize them, campuses should focus on creating meaningful dialogue about the specific, formal services available on their campus. Such discussions will aid in the implementation of effective rape resistance strategies and expanded campus services. In addition, because of the surveyed sorority women's fear of publicly speaking about sexual assault, colleges and universities should evaluate the need for anonymous tip lines and help lines via telephone or text. With such anonymous services, sorority women may feel more inclined to make reports of sexual assault to the formal authorities without fear of harassment within the Greek community. Further, the \#MeToo movement has caused students, including sorority members, and researchers to call for administrators and faculty to address the rape culture on college campuses (Radina, 2017).

As this was the first known inquiry into sorority women's perceptions of sexual assault survivors' services, future research should build on the current inquiry's attempt to address sorority women's need for services related to the prevention and reduction of sexual violence. Additionally, future inquiries should incorporate multiple universities in multiple geographical locations and make methodological choices that would provide the most opportunity for dialogue among the researcher and participants. Future research could incorporate qualitative analyses of interviews to provide for saturation of themes. In the same fashion, researchers should continue to build relationships with sorority women in order to gain access to this group that experiences sexual assault at such a high rate (e.g., Barnes et al., 2021) and reports a lack of trust in survivors' services. Ultimately, future research should attempt to continue the work of the current study in many locations, with a larger and more racially and ethnically diverse sample, and across many universities with the goal of increasing dialogue among sorority women and researchers and implementing changes to help this population. 


\section{ACKNOWLEDGMENTS}

The authors would like to thank the anonymous reviewers for their careful feedback and Editor-in-Chief, Donna Hughes, for all of her time, attention, and hard work in assisting us. Dignity thanks the following reviewers for their time, expertise, and recommendations: Kathryn Quina, Associate Dean, emerita, University of Rhode Island, USA; John D. Foubert, Dean, Union University, USA; and Jody Raphael, Senior Researcher (emerita), DePaul University College of Law, USA.

\section{AUTHOR BIOGRAPHIES}

Andrea Giuffre is doctoral candidate in the Department of Criminology and Criminal Justice at The University of Missouri - St. Louis (UMSL). Prior to arriving at UMSL, she obtained a Master of Arts in Criminal Justice with a specialization in Victimology from Seattle University. Her primary research interests include the impact of identity formation on desistance, the social harms of criminal legal system contact, the financialization of the criminal legal system, monetary sanctions, and corrections. Giuffre currently works with Drs. Beth Huebner and Lee Slocum on the CUNY Institute for State and Local Governance's "Probation Violations as a Driver of Jail Incarceration in St. Louis County, Missouri."

Elaine Gunnison is Professor/Graduate Director in the Criminal Justice Department at Seattle University. She has a Ph.D. in Criminal Justice from the University of Cincinnati with a specialization in life course criminology, female offending, and corrections. Her research interests include the applicability of criminological theory to females and ex-offender reentry. Her research has been published in: Crime \& Delinquency, Criminal Justice Studies, Federal Probation, The Journal of Criminal Justice, The Journal of International \& Comparative Criminal Justice, The Journal of Crime \& Justice, Women \& Criminal Justice, The Journal of Qualitative Criminal Justice \& Criminology, The Journal of Prison Education \& Reentry, The Journal of Interpersonal Violence, and Criminology, Criminal Justice, Law \& Society. She is lead/sole author of several books: Offender Reentry: Beyond Crime \& Punishment (Lynne Rienner); Women \& Crime: Balancing the Scales (Wiley-Blackwell); Community Corrections (Carolina Academic Press); and Women Leading Justice: Experiences and Insights (Routledge). She recently served as Co-PI on an academic-practitioner research initiative, the Seattle Women's Reentry Initiative. She is also currently serving as Co-Editor of Criminology, Criminal Justice, Law \& Society. She is a member of the Academy of Criminal Justice Sciences, the American Society of Criminology, and the Western Society of Criminology.

\section{RECOMMENDED CITATION}

Giuffre, Andrea \& Gunnison, Elaine. (2022). Sorority women's perceptions of survivors' services and justice on an urban campus. Dignity: A Journal of Analysis Exploitation and Violence. Vol. 7, Issue 1, Article 3. https://doi.org/10.23860/dignity.2022.07.01.03 Available at http://digitalcommons.uri.edu/dignity/vol7/iss1/3.

\section{REFERENCES}

Ahrens, C. E., Campbell, R., Ternier-Thames, N. K., Wasco, S. M., \& Sefl, T. (2007). Deciding whom to tell: Expectations and outcomes of rape survivors first disclosures. Psychology of Women Quarterly, 31(1), 38-49. https://doi.org/10.1111/j.14716402.2007.00329.x

Amstadter, A., Zinzow, H., Mccauley, J., Strachan, M., Ruggiero, K., Resnick, H., \& Kilpatrick, D. (2010). Prevalence and correlates of service utilization and help seeking in a national college sample of female rape victims. Journal of Anxiety Disorders, 24(8), 900-2. https://doi.org/10.1016/j.janxdis.2010.06.014 
Anson, J. L., \& Marchesani, R. F. (1991). Baird's manual of American college fraternities $\left(20^{\text {th }}\right.$ ed.). Baird's Manual Foundation.

Atlas, G., \& Morier, D. (1994). The sorority rush process: Self-selection, acceptance criteria, and the effect of rejection. Journal of College Student Development, 35(5), 346-353.

Barnes, M. L., Adams-Clark, A., Rosenthal, M. N., Smith, C. P., \& Freyd, J. J. (2021). Pledged into harm: Sorority and fraternity members face increased risk of sexual assault and sexual harassment. Dignity: A Journal of Analysis of Exploitation and Violence, 6(1), 130. https://doi.org/10.23860/dignity.2021.06.01.09

Blumer, H. (1954). What is wrong with social theory? American Sociological Review, 19(5), 310. https://doi.org/10.2307/2088165

Campbell, R., Goodman-Williams, R., \& Javorka, M. (2019). A trauma-informed approach to sexual violence research ethics and open science. Journal of Interpersonal Violence, 34(23-24), 4765-4793. https://doi.org/10.1177/0886260519871530

Campbell, R., \& Raja, S. (2005). The sexual assault and secondary victimization of female veterans: Help-seeking experiences with military and civilian social systems. Psychology of Women Quarterly, 29(1), 97-106. https://doi.org/10.1111/j.14716402.2005.00171.x

Canan, S., Jozkowski, K., \& Crawford, B. (2016). Sexual assault supportive attitudes: Rape myth acceptance and token resistance in Greek and non-Greek college students from two university samples in the United States. Journal of Interpersonal Violence, 33(22), 3502-3530. https://doi.org/10.1177/0886260516636064

Cerrito, C. (2019, September). Greek life often reinforces gender stereotypes, but it doesn't have to. The Daily Orange. http://dailyorange.com/2019/09/greek-life-oftenreinforces-gender-stereotypes-doesnt/

Deamicis, C. (2013, May 20). Which matters more: Reporting assault or respecting a victim's wishes? The Atlantic. https://www.theatlantic.com/national/archive/2013/05/which-matters-morereporting-assault-or-respecting-a-victims-wishes/276042/

Dworkin, E., Pittenger, S., \& Allen, N. (2016). Disclosing sexual assault within social networks: A mixed-method investigation. American Journal of Community Psychology, 57(1-2), 216-228. https://doi.org/10.1002/ajcp.12033

Finch, J. (1987). The vignette technique in survey research. Sociology, 21(1), 105-114. https://doi.org/10.1177/0038038587021001008

Fisher, B. S., Daigle, L. E., Cullen, F. T., \& Turner, M. G. (2003). Reporting sexual victimization to the police and others: Results from a national-level study of college women. Criminal Justice and Behavior, 30(1), 6-38. https://doi.org/10.1177/0093854802239161

Follingstad, D. R., Caihong, R. L., Chahal, J. K., \& Renzetti, C. M. (2021). Students' perceptions of justice: Application of sanctions, guilt, and responsibility in campus sexual assault cases. Journal of Family Violence, 36(3), 307-324. https://doi.org/10.1007/s10896020-00129-5

Foxx, R. M., Martella, R. C., \& Marchand-Martella, N. E. (1989). The acquisition, maintenance, and generalization of problem-solving skills by closed head-injured adults. Behavior Therapy, 20(1), 61-76. https://doi.org/10.1016/S0005-7894(89)80118-2

Franklin, C. (2010). Physically forced, alcohol-induced, and verbally coerced sexual victimization: Assessing risk factors among university women. Journal of Criminal Justice, 38(2), 149-159. https://doi.org/10.1016/j.jcrimjus.2010.02.004

Franklin, C. (2016). Sorority affiliation and sexual assault victimization: Assessing vulnerability using path analysis. Violence Against Women, 22(8), 895-922. https://doi.org/10.1177/1077801215614971 
Friedenberg, J., Mulvihill, M., \& Caraballo, L. R. (1993). From ethnography to survey: Some methodological issues in research on health seeking in East Harlem. Human Organization, 52(2), 151-161. https://doi.org/10.17730/humo.52.2.420w0152552n2j78

Glaser, B. G. (1978). Theoretical Sensitivity. Sociology Press.

Glaser, B. G., \& Strauss, A. L. (1967). The discovery of grounded theory: Strategies for qualitative research. Aldine Pub. Co.

Goodmark, L. (2015). "Law and justice are not always the same": Creating community-based justice forums for people subjected to intimate partner abuse. Florida State University Law Review, 42(3), 707-764.

Grigoriadis, V. (2017). Blurred lines: Rethinking sex, power, and consent on campus. Houghton Mifflin Harcourt.

Guerette, S. M., \& Caron, S. L. (2007). Assessing the impact of acquaintance rape: Interviews with women who are victims/survivors of sexual assault while in college. Journal of College Student Psychotherapy, 22(2), 31-50. https://doi.org/10.1300/j035v22n02 04

Gunnison, E., Bernat, F. P., \& Goodstein, L. (2016). Women, crime, and justice: Balancing the scales. Wiley-Blackwell.

Herman, J. L. (2005). Justice from the victim's perspective. Violence Against Women, 11(5), 571-602. https://doi.org/10.1177/1077801205274450

Holland, K., \& Cortina, L. (2017). "It happens to girls all the time": Examining sexual assault survivors' reasons for not using campus supports. American Journal of Community Psychology, 59(1-2), 50-64. https://doi.org/10.1002/ajcp.12126

Hughes, R., \& Huby, M. (2004). The construction and interpretation of vignettes in social research. Social Work \& Social Sciences Review, 11(1), 36-51.

https://doi.org/10.1921/17466105.11.1.36

Jülich, S. (2006). Views of justice among survivors of historical child sexual abuse: Implications for restorative justice in New Zealand. Theoretical Criminology, 10(1), 125-138. https://doi.org/10.1177/1362480606059988

Kaufer Busch, E. (2018). Sexual assault: What's Title IX got to do with it? Perspectives on Political Science, 47(2), 104-114. https://doi.org/10.1080/10457097.2017.1331682

Kaukinen, C., \& DeMaris, A. (2009). Sexual assault and current mental health: The role of help-seeking and police response. Violence Against Women, 15(11), 1331-1357. https://doi.org/10.1177/1077801209346713

Kendall, E., Shum, D., Halson, D., Bunning, S., \& Teh, M. (1997). The assessment of social problem-solving ability following traumatic brain injury. Journal of Head Trauma and Rehabilitation, 12(3), 68-78. https://doi.org/10.1097/00001199-199706000-00007

Kim, H-J., \& Fredriksen-Goldsen, K. I. (2013). Nonresponse to a question on self-identified sexual orientation in a public health survey and its relationship to race and ethnicity. American Journal of Public Health, 103(1), 67-69. https://doi.org/10.2105/ajph.2012.300835

Kingree, J. B., \& Thompson, M. (2020). Sorority membership and sexual victimization: An examination of potential mediators of the association. Journal of interpersonal violence, 35(23-24), 5834-5852. https://doi.org/10.1177/0886260517723745

Lake, P. F. (2009). Student discipline: The case against legalistic approaches. Chronical of Higher Education, 55(32), A31-A32.

Lonsway, K. A., \& Archambault, J. (2012). The "justice gap" for sexual assault cases: Future directions for research and reform. Violence Against Women, 18(2), 145168. https://doi.org/10.1177/1077801212440017 
McGlynn, C., \& Westmarland, N. (2019). Kaleidoscopic justice: Sexual violence and victimsurvivors' perceptions of justice. Social \& Legal Studies, 28(2), 179-201. https://doi.org/10.1177/0964663918761200

Mellins, C. A., Walsh, K., Sarvet, A. L., Wall, M., Gilbert, L., Santelli, J. S., Thompson, M., Wilson, P. A., Khan, S., Benson, S., Bah, K., Kaufman, K. A., Reardon, L., \& Hirsch, J. S. (2017). Sexual assault incidents among college undergraduates: Prevalence and factors associated with risk. PLoS One, 12(11), e0186471. https://doi.org/10.1371/journal.pone.0186471

Minow, J., \& Einolf, C. (2009). Sorority participation and sexual assault risk. Violence Against Women, 15(7), 835-851. https://doi.org/10.1177/1077801209334472

Mohler-Kuo, M., Dowdall, G. W., Koss, M. P., \& Wechsler, H. (2004). Correlates of rape while intoxicated in a national sample of college women. Journal of Studies on Alcohol, 65(1), 37-45. https://doi.org/10.15288/isa.2004.65.37

Mongell, S., \& Roth, A. (1991). Sorority rush as a two-sided matching mechanism. The American Economic Review, 81(3), 441-464.

Muehlenhard, C., \& Hollabaugh, L. C. (1988). Do women sometimes say no when they mean yes? The prevalence and correlates of women's token resistance to sex. Journal of Personality and Social Psychology, 54(5), 872-879. https://doi.org/10.1037/0022$\underline{3514.54 .5 .872}$

Mustaine, E. E., \& Tewksbury, R. (2002). Sexual assault of college women: A feminist interpretation of a routine activities analysis. Criminal Justice Review, 27(1), 89-123. https://doi.org/10.1177/073401680202700106

National Panhellenic Conference. (2021). Our member organizations. NPCwomen.org. http://npcwomen.org/about/our-member-organizations/

Norris, J., Nurius, P. S., \& Graham, T. L. (1999). When a date changes from fun to dangerous: Factors affecting women's ability to distinguish. Violence Against Women, 5(3), 230250. https://doi.org/10.1177/10778019922181202

Orchowski, L., \& Gidycz, C. (2012). To whom do college women confide following sexual assault? A prospective study of predictors of sexual assault disclosure and social reactions. Violence Against Women, 18(3), 264-288.

https://doi.org/10.1177/1077801212442917

Orchowski, L. M., Meyer, D. H., \& Gidycz, C. A. (2009). College women's likelihood to report unwanted sexual victimization to campus agencies: Trends and correlates. Journal of Aggression, Maltreatment \& Trauma, 18(8), 839-858. https://doi.org/10.1080/10926770903291779

Orth, U. (2002). Secondary victimization of crime victims by criminal proceedings. Social Justice Research, 15(4), 313-325. https://doi.org/10.1163/157181796x00122

Patterson, D., \& Campbell, R. (2010). Why rape survivors participate in the criminal justice system. Journal of Community Psychology, 38(2), 191-205. https://doi.org/10.1002/jcop.20359

Radina, M. E. (2017). Sisterhood and sexual assault: Engaging sorority members in dialogue, critical analysis, and feminist praxis. Family Relations, 66(1), 126-138. https://doi.org/10.1111/fare.12234

Robbins, A. (2015, January 30). How sorority culture contributes to the campus rape problem. The Washington Post. https://www.washingtonpost.com/posteverything/wp/2015/01/30/how-sororityculture-contributes-to-the-campus-rape-problem/

Rubin, H. J., \& Rubin, I. S. (2016). Qualitative interviewing: The art of hearing data (3rd ed.). Sage.

Saldana, J. (2016). The coding manual for qualitative researchers ( $3^{\text {rd }}$ ed.). Sage. 
Scott-Sheldon, L. A. J., Carey, K. B., \& Carey, M. P. (2008). Health behavior and college students: Does Greek affiliation matter? Journal of Behavioral Medicine, 31(1), 61-70. https://doi.org/10.1007/s10865-007-9136-1

Shapiro, T. R. (2015, April 13). Fraternities and sororities team up for sex assault prevention. The Washington Post. https://www.washingtonpost.com/news/gradepoint/wp/2015/04/13/fraternities-and-sororities-team-up-for-sex-assaultprevention/

Sinozich, S., \& Langton, L. (2014). Rape and sexual assault victimization among college-age females, 1995-2013. U.S. Department of Justice. https://bjs.ojp.gov/content/pub/pdf/rsavcaf9513.pdf

Spencer, C., Mallory, A., Toews, M., Stith, S., \& Wood, L. (2017). Why sexual assault survivors do not report to universities: A feminist analysis. Family Relations, 66(1), 166-179. https://doi.org/10.1111/fare.12241

Starzynski, L. L., Ullman, S. E., Filipas, H. H., \& Townsend, S. M. (2005). Correlates of women's sexual assault disclosure to informal and formal support sources. Violence and Victims, 20(4), 417-432. https://doi.org/10.1891/088667005780927593

Stoner, J. E., \& Cramer, R. J. (2019). Sexual violence victimization among college females: A systematic review of rates, barriers, and facilitators of health service utilization on campus. Trauma, Violence, \& Abuse, 20(4), 1-14. https://doi.org/10.1177/1524838017721245

Sweet, S. (2004). Understanding fraternity hazing. In H. Nuwer (Ed.), The hazing reader (pp.1- 13). Indiana University Press.

Wechsler, H., \& Nelson, T. (2001). Binge drinking and the American college student: What's five drinks? Psychology of Addictive Behaviors: Journal of the Society of Psychologists in Addictive Behaviors, 15(4), 287-291. https://doi.org/10.1037//0893$\underline{164 x .15 .4 .287}$

Wuthrich, C. K. (2009). Reflections on personal responsibility: Sorority members at risk for interpersonal violence. NASPA Journal, 46(2), 228-257.

https://doi.org/10.2202/1949-6605.6040. 